\title{
Use of the co-composting time extract agar to evaluate the microbial community changes during the co-composting of activated sludge and date palm waste
}

\author{
Loubna El Fels $^{1} \cdot$ Yedir Ouhdouch $^{2} \cdot$ Mohamed Hafidi $^{1}$
}

Received: 7 October 2014/ Accepted: 3 March 2015/Published online: 13 March 2015

(c) The Author(s) 2015. This article is published with open access at Springerlink.com

\begin{abstract}
This study investigates changes in the microbiological community of two co-composting mixtures of activated sludge and date palm waste over a 6-month period. The use of the co-composting time extract medium to evaluate the abundance of cultivable indigenous microflora showed that the total microbial biomass was higher during the thermophilic phase. The mesophilic microflora was more abundant than the thermophilic bacteria, throughout the co-composting process. The proportion of mesophilic and thermophilic actinobacteria was high during the maturation phase especially for mixture A. However, thermotolerant fungal microflora increased during the thermophilic stage. Furthermore, correlating physico-chemical analysis of samples with bacterial diversity indicated that the bacterial communities underwent temperature changes. Enterococci and thermotolerant coliforms decreased significantly toward the end of the co-composting process which indicates the safety and sanitization of the end product.
\end{abstract}

Keywords Active sludge compost - Composting time extract agar - Indigenous microflora abundance and succession · Thermotolerant fungi · Coliforms

Mohamed Hafidi

hafidi.ucam@gmail.com; hafidi@uca.ma

1 Laboratory of Ecology and Environment (L2E) (Unit Associated with the CNRST, URAC32), Faculty of Science Semlalia, Cadi Ayyad University, BP: 2390, Marrakech, Morocco

2 Laboratory of Biology and Biotechnology of Microorganisms, Faculty of Science Semlalia, Cadi Ayyad University, BP: 2390, Marrakech, Morocco

\section{Introduction}

It has been demonstrated that composts can be applied to agricultural fields as long-term fertiliser to improve soil structure (Jakobsen 1995; Barje et al. 2012). The evolution and the performance of the composting process are dependent on the microorganisms that populate composted substrates and are able to degrade the organic waste (Chroni et al. 2009). During the composting process, the microbial metabolic pathway influences the physico-chemical parameters, which in turn lead to changes of microbial community succession. In order to evaluate the process and the end product biotransformation, better knowledge of the functional microbial community dynamics is needed. Steger et al. (2007) showed that knowledge of the microorganism composition in composts, their community structure and the microbial succession should help to ensure high quality of the final compost product. It has been underlined that microbial activity during composting is mainly due to the mesophilic microbial community, such as (bacteria, fungi and actinobacteria) which play an important role in breaking down the organic compounds to humus-like material (Finstein and Morris 1975; Herrmann and Shann 1997; Ryckeboer et al. 2003).

The final composts should not contain pathogens or viable seeds and it should be stable and suitable for use as soil amendment (Epstein 1997; Tønner-Klank et al. 2007). Faecal matter is known to contain high numbers of naturally occurring enteric bacteria, and occasionally, disease-causing pathogens like bacteria, enteric viruses and parasites, which requires that the hygienic quality of treated organic faecal waste be ensured.

Sludge and date palm co-composting is an unexplored environment. In this context, the succession of indigenous 
microflora from this habitat has not been investigated. Current knowledge of the compost microbial community is based on different approaches such as direct analysis of phospholipid fatty acid patterns (PLFA) (Klammer and Baath 1998) or molecular techniques (Riddech et al. 2002). Various standard growth media are used for monitoring the cultivable microflora during composting such as malt extract agar (Wei et al. 2007). However, co-composting time extract agar was used as a selective media of only functional microflora able to degrade composted substrates (El Fels et al. 2014a). This plays a significant role to ensure that the microbial community composition is able to grow and transform the substrate available at given composting times, $\mathrm{pH}$ and temperatures.

The main objective of this study was to investigate the use of the co-composting time extract medium to evaluate the abundance and to assess the microbial community function in sewage sludge/date palm co-composting.

\section{Materials and methods}

\section{Co-composting trials}

Co-composting trials were conducted on a composting platform over a period of 6 months. Two trials with different proportions of mixed sewage sludge/palm waste were run:

- Mixture A: $1 / 3$ sludge + date palm tree waste $2 / 3$, total volume: $4 \mathrm{~m}^{3}$

- Mixture B: $1 / 2$ sludge + date palm tree waste $1 / 2$, total volume: $4 \mathrm{~m}^{3}$.

Each mixture was carefully homogenized, moisture was adjusted to $60 \%$ (optimal value for composting) and then the mixtures were windrowed. Windrows were turned over by hand weekly to aerate the mixture. Homogeneous samples were taken at $T_{0}$ (first day of co-composting) and after each airing (aerating the mixture). Homogeneous samples $(1 \mathrm{~kg})$ were obtained by careful mixing of several sub samples taken at different points (height and length) of the windrow and quartering. The samples were kept at $-20{ }^{\circ} \mathrm{C}$ before analysis.

\section{Physico-chemical analysis}

The temperature was measured every day at different levels (height and length) of the windrow using sensors with data memory (PH0700115 model 1.20, Ector Traceability software, ECTOR France). The samples were dried out at $105^{\circ} \mathrm{C}$. The $\mathrm{pH}$ was measured in an aqueous extract of the compost at room temperature $(1 \mathrm{~g} / 10 \mathrm{ml}$ of distilled water) according to NF ISO 10390. Total organic carbon and Ash content were calculated after calcinations in a muffle furnace at $600{ }^{\circ} \mathrm{C}$ for $6 \mathrm{~h}$. Total Kjeldahl nitrogen (TKN) was assayed in $0.5 \mathrm{~g}$ samples using classical Kjeldahl procedure and by steam distillation according to AFNOR T90-1110 standard. The physico-chemical parameters were analysed as mentioned in our previous study (El Fels et al. 2014a, b).

\section{Biological analysis}

\section{Enumeration of cultivable indigenous microflora}

Samples of each co-composting time $(0,15,22,30,60,90$ and 180 days) were first mixed, suspended in sterile distilled water $(10 \mathrm{~g}$ in $100 \mathrm{ml})$ homogenized by vortexing and finally treated 10 to 15 min by sonication according to Ouhdouch et al. (2001); El Fels et al. (2014a) All treated samples were serially diluted up to $10^{-6}$ and functional microflora enumerated by plating and spreading $0.1 \mathrm{ml}$ of $10^{-4}, 10^{-5}$ and $10^{-6}$ dilutions over the surface of the co-composting time extracts agar (CTEA) prepared according to El Fels et al. (2014a) as follows: One litre of distilled water and $35 \mathrm{~g}$ of co-composting time sample were mixed overnight. Agar $(15 \mathrm{~g})$ was added to the filtrate collected after it had been filtered and sterilized at $120{ }^{\circ} \mathrm{C}$ for $15 \mathrm{~min}$. The $\mathrm{pH}$ was adjusted to that of the cocomposting time before sterilization. For each co-composting time, the plates were incubated at $28^{\circ} \mathrm{C}$ for mesophilic and $45{ }^{\circ} \mathrm{C}$ for thermophilic microflora enumeration.

For actinobacteria enumeration, the media were supplemented with $40 \mu \mathrm{g} / \mathrm{ml}$ of actidione to inhibit the development of fungi (Olson 1968) and $10 \mu \mathrm{g} / \mathrm{ml}$ of nalidixic acid to inhibit the Gram-negative bacteria capable of swarming without affecting the growth of actinobacteria (Bulina et al. 1997; Barakate et al. 2002). For fungus evaluation, the media were supplemented with $5 \mu \mathrm{g} / \mathrm{ml}$ of chloramphenicol to inhibit the development of bacteria. For other microorganisms, the media were supplemented with $40 \mu \mathrm{g} / \mathrm{ml}$ of actidione to inhibit the development of fungi. After 7 days of incubation, the actinobacteria were recognized on the basis of morphological and microscopic features following directions given by International Streptomyces Project (ISP) (Shirling and Gottlieb 1966).

For the initial and final co-composting time, total coliform and thermotolerant coliform counts were determined on desoxycholate $(0.1 \%)$ lactose agar (Biokar diagnostics) after incubation for $24 \mathrm{~h}$ at 37 and $44{ }^{\circ} \mathrm{C}$, respectively. Microbial analyses were performed in triplicate.

\section{Statistical analysis}

The results are presented in the form of averages \pm SEM (standard error of the mean). Comparison of the averages was made by ANOVA. The differences are considered significant at $p<5 \%$. 
Principal components analysis (PCA) was applied to the correlation matrix between microflora succession and physical-chemical variables. The statistical treatments were carried out using the software SPSS win version 10.

\section{Results and discussion}

\section{Physical-chemical characterisation}

The species composition changed markedly as composting progressed, and particular correlations could be drawn between the biological and physico-chemical states of the material (El Fels et al. 2014a, b). In the present example (Fig. 1), the temperature indicates a typical co-composting pattern characterised by two major phases: A thermophilic (stabilization) phase is characterised by a rise in temperature, which peaked at $65^{\circ} \mathrm{C}$. This is the result of intense microbial activity resulting from the degradation of the simple molecules present in the substrate (Barje et al. 2012; El Fels et al. 2014a, b). The maturation phase is characterised by a decrease of temperature due to the exhaustion of easily metabolisable organic compounds from the medium, with compounds that are only resistant to degradation (e.g. lignin, cellulose) (Amir et al. 2005).

The principal characteristics of sludge using of composting are $\mathrm{C} / \mathrm{N}$ around 20.8, moisture content $46.46 \pm 0.26$ and TKN $1.5 \pm 0.2$.

The mean features of co-composting products are presented in Table 1; the final products presented a $\mathrm{C} / \mathrm{N}$ ratio of around $10, \mathrm{NH}_{4}{ }^{+} / \mathrm{NO}_{3}{ }^{-} \leq 1$, which provides information on the importance of organic matter oxidation and a significant degree of stability of substrate. As indicated in the literature these values confirm the maturity of the compost (Barje et al. 2012; El Fels et al. 2014b).

\section{Coliforms versus time of co-composting process}

Most published work has used enterococci and thermotolerant coliforms as faecal contamination indicator organisms (Redlinger et al. 2001). Their presence indicates poor hygiene. During co-composting, we noted a significant decrease of the order of $90 \%$ toward the end of co-composting (Table 1). For compost hygiene, the recommended Faecal Coliform (FC) and Faecal Streptococcus (FS) densities are of $5 \times 10^{2}$ bacteria/g and $5 \times 10^{3}$ bacteria/g (Vuorinen and Saharinen 1997; Bhatia et al. 2013), respectively.

The removal of coliforms is presumably linked to the physical co-composting parameters, especially the high temperature and unfavourable growth conditions established during the thermophilic phase. Several authors (Gaspard and Schwartzbrod 2003; Cofie et al. 2006; Koné et al. 2007; El Fels et al. 2014b) showed that the rise of temperature during the thermopilic stage leads to hygeinization. Furthermore, Redlinger et al. (2001); Pietronave et al. (2004) and Bhatia et al. (2013) noted that a significant decrease of faecal coliforms and faecal Streptococci during composting. Paniel et al. (2010) demonstrated that faecal Enterococcus was not observed during the stabilization phase. Palmisano and Barlaz (1996); Lung et al. (2001); Tønner-Klank et al. (2007) showed that proper composting can kill many human pathogens in different types of compost, and the temperatures achieved during the treatment $\left(50-70{ }^{\circ} \mathrm{C}\right)$ are able to kill the enteric pathogens. This stage of the process is defined as disinfection or sanitization.

In spite of the abundance of faecal coliforms in sewage sludge, the results indicate the good hygienic quality of the end products of co-composted sewage sludge and date palm waste.
Fig. 1 Temperature versus time during the co-composting process for two mixtures $\mathrm{A}$ (a) and B (b), according to El Fels et al. (2014b)
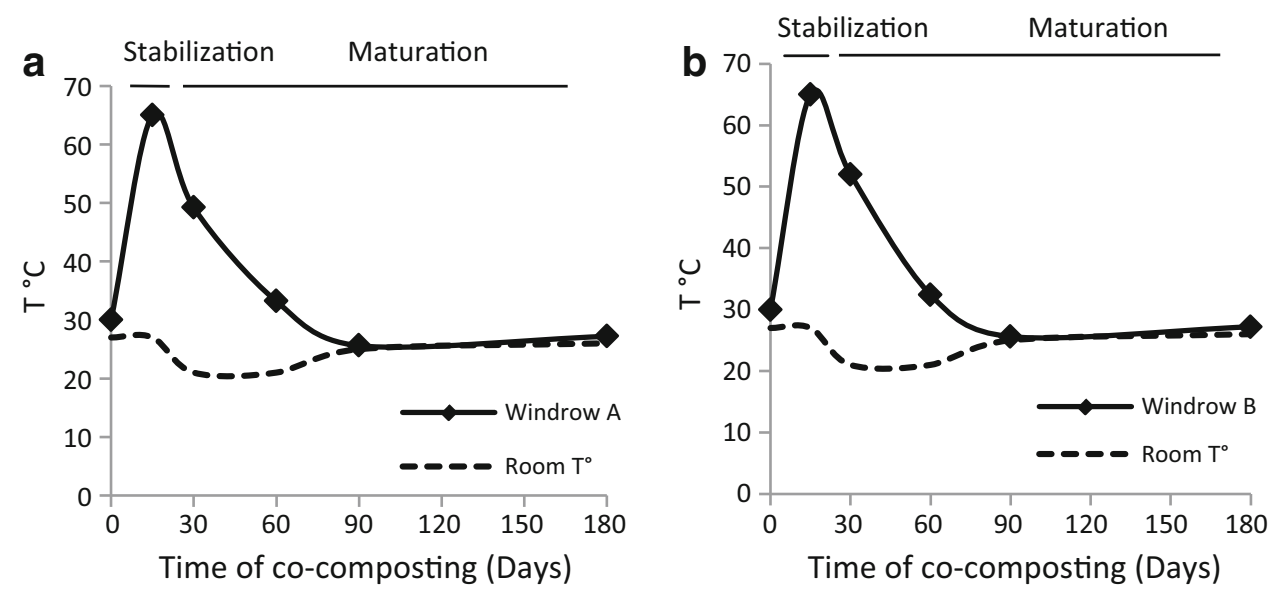
Table 1 Physico-chemical and biological parameters during co-composting for mixtures A and B

\begin{tabular}{llllllllll}
\hline Mixture & $\begin{array}{l}\text { Time of co-composting } \\
\text { (day) }\end{array}$ & $\% \mathrm{TKN}^{\mathrm{a}}$ & $\begin{array}{l}\text { Moisture } \\
(\%)\end{array}$ & $\mathrm{NH}_{4}{ }^{+} / \mathrm{NO}_{3}{ }^{-}$ & $\mathrm{C} / \mathrm{N}$ & $\mathrm{DEC}(\%)^{\mathrm{a}}$ & $\mathrm{pH}$ & $\mathrm{FC} \mathrm{UFC/g}$ & $\mathrm{TC} \mathrm{UFC} / \mathrm{g}$ \\
\hline $\mathrm{A}$ & $T_{0}$ & $1.31 \pm 1.2$ & 58.83 & 13.75 & 26.2 & - & $6.34 \pm 0.03$ & $12 \times 10^{4}$ & $345 \times 10^{4}$ \\
& $T_{180}$ & $2.18 \pm 1.1$ & 66 & 0.12 & 10.09 & $40.07 \pm 1.1$ & $6.79 \pm 0.06$ & $\leq 85$ & $\leq 125$ \\
$\mathrm{~B}$ & $T_{0}$ & $1.28 \pm 1.09$ & 60.97 & 15.6 & 27.4 & - & $6.04 \pm 0.28$ & $2 \times 10^{4}$ & $456 \times 10^{4}$ \\
& $T_{180}$ & $2.28 \pm 1.21$ & 66 & 0.14 & 10.08 & $40 \pm 1.49$ & $7.03 \pm 0.08$ & $\leq 90$ & $\leq 175$ \\
\hline
\end{tabular}

$T K N$ total Kjeldahl nitrogen, $D E C$ decomposition rate, $F C$ faecal coliforms, $T C$ total coliforms

${ }^{a}$ Results expressed per unit weight dry matter

\section{Indigenous microflora abundances during co- composting}

In this study, both mesophilic and thermophilic microflora evolution showed a peak during the thermophilic stage for mixtures $\mathrm{A}$ and $\mathrm{B}$. The total mesophilic microflora increased from $43 \times 10^{8}$ to $137 \times 10^{8} \mathrm{CFU} / \mathrm{g}$ on day 22 (thermophilic phase), and from $63 \times 10^{8}$ to $294 \times 10^{8}$ CFU/g (Fig. 2); the evolution of thermophilic microflora in CTEA medium varied in the range from $5.4 \times 10^{8}$ to $40 \times 10^{8} \mathrm{CFU} / \mathrm{g}$, and from $7.7 \times 10^{8}$ to $114 \times 10^{8} \mathrm{CFU} / \mathrm{g}$ for mixtures A and B, respectively (Fig. 2) (El Fels et al. 2014a).

These high values during the thermophilic phase could result from the high levels of mesophilic microflora and especially that of thermotolerant microflora in the cocomposted substrates (El Fels et al. 2014a). However, the mesophilic microflora were more abundant than thermophilic microflora. It was also noted that mixture B microflora abundance was greater than that of mixture A. These results could be related to the higher proportion of sewage sludge in mixture $B$ and resulting abundance of mesophilic microflora rate (El Fels et al. 2014a). Thereafter all mesophilic and thermophilic microflora abundances declined at maturation stage. Sneath (1986), demonstrating that temperatures from $26-48{ }^{\circ} \mathrm{C}$ lead to favourable conditions for the growth of actinomycetes and of other heattolerant bacteria. Hassen et al. (2001); Marshall et al. (2004); Bhatia et al. (2013), showed that the initial phase of the composting process is characterised by the intense activity and growth of mesophilic microflora which reach abundances two to four orders of magnitude higher than the thermophilic group. Chroni et al. (2009) demonstrated that relatively low temperatures (around $50{ }^{\circ} \mathrm{C}$ ) seem to facilitate the survival of total mesophilic bacteria.

At the beginning of co-composting, the mesophilic microflora start vigorous oxidation of easily biodegradable compounds. This intense microbial activity leads to a rapid increase in temperature which improves the development and proliferation of total thermotolerant followed by thermophilic microflora. This group becomes responsible for the degradation process during the stabilization phase. Total microflora abundances declined after only the first month of co-composting. This could be related to the restricted conditions, particularly the loss of easily metabolisable substrates. The decrease of temperature affects thermophilic microflora development and promotes the relocation of the new mesophilic microflora. This result
Fig. 2 Mesophilic and thermophilic microflora evolution during co-composting of mixture $\mathrm{A}$ and $\mathrm{B}$ on CTEA medium, according to El Fels et al. (2014a). TM thermophilic microflora, $M M$ mesophilic microflora, CTEA cocomposting time extract agar
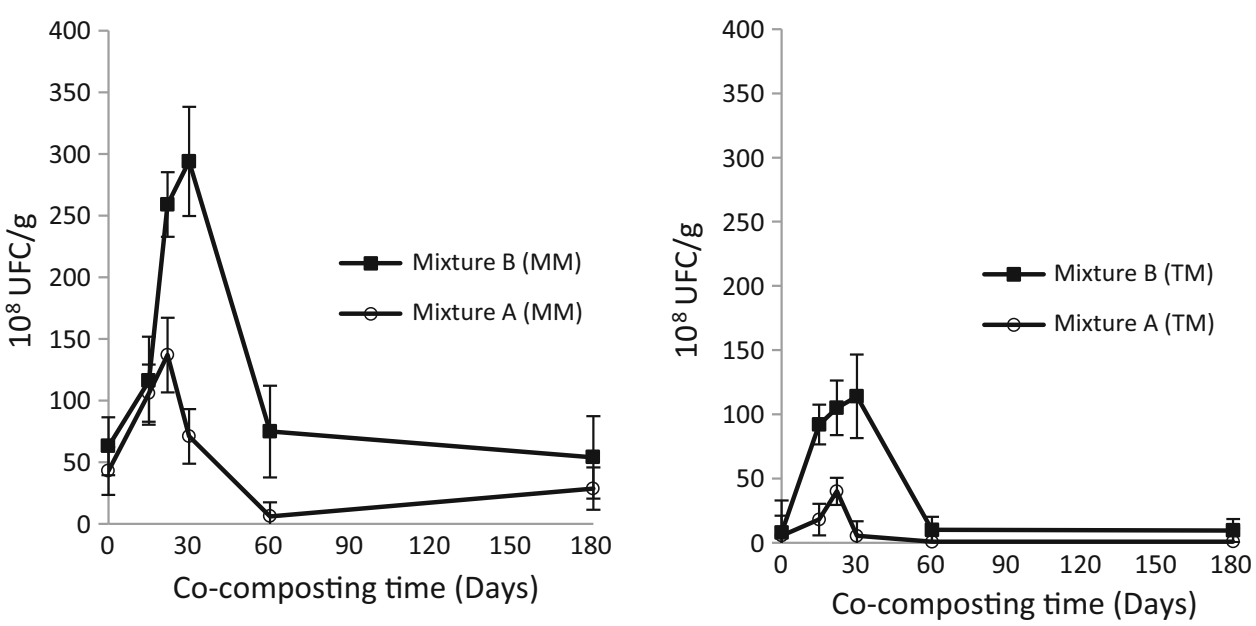
is in line with data reported by Tønner-Klank et al. (2007). Chroni et al. (2009) showed that most of the microbial groups examined exhibited their highest counts towards the end of the thermophilic phase.

Many factors such as oxygen content, moisture, composition of the raw composted substrate, $\mathrm{pH}$ and temperature affect the succession of microbial communities during composting. Paul and Clark (1996), showed that the rapid changes of physicochemical conditions in composting processes are likely to select for a succession of different microbial communities. It could be expected that temperature and the availability of substrates are the main factors. Sidhu et al. (2000) showed that the overall population of bacteria declined with compost maturity.

A difference was noted between mixtures A and B. The thermophilic phase determined by the indigenous microflora was limited to 22 days for mixture A but reached 30 days for mixture B (El Fels et al. 2014a). In this study, the actinobacteria, which proliferate during the maturation phase, show a significant development at 60 and 90 days, for mixtures $\mathrm{A}$ and $\mathrm{B}$, respectively (Fig. 3a, b). This observation is confirmed by a significant correlation between actinobacteria and maturation phase according to PCA (Fig. 4a, b). This difference could be attributed to the higher concentration of lignocellulosic substrate in mixture A. Filippi et al. (2002) identified that some products cause a temporary lag-phase in the decomposition of the organic fraction during composting. Adani et al. (2001) showed that the oxygen level, organic matter stabilization and moisture limitation generate a biological activity lag-phase.

Indigenous microflora dynamics allowed a distinction between two composting main phases, thermophilic and maturation, which characterise of the progression of the composting process. This suggests that the indigenous microflora play a significant role in the degradation of matter and in the maturity of the co-composting process of sewage sludge and date palm.

\section{Enumeration of mesophilic and thermophilic indigenous microflora groups}

Three main aerobic microorganisms were monitored in the microbiological analysis of co-composting stages: fungi, actinobacteria and other bacteria. These microorganisms belong to the dominating taxa and functional groups present during co-composting. Finstein and Morris (1975); De Bertoldi et al. (1983) and Marshall et al. (2004) showed that microbiological activity as composting advances can be attributed to different groups of microorganisms such as the total aerobic mesophilic microflora (TAM).

Functional mesophilic and thermophilic actinobacteria show a peak of about 80 and $70 \%$ for the mesophilc, and
Fig. 3 a Mesophilic indigenous microflora groups during cocomposting process

Fungi $=$ Moulds and yeasts. b Thermophilic microflora groups versus time of cocomposting Fungi $=$ Moulds and yeasts
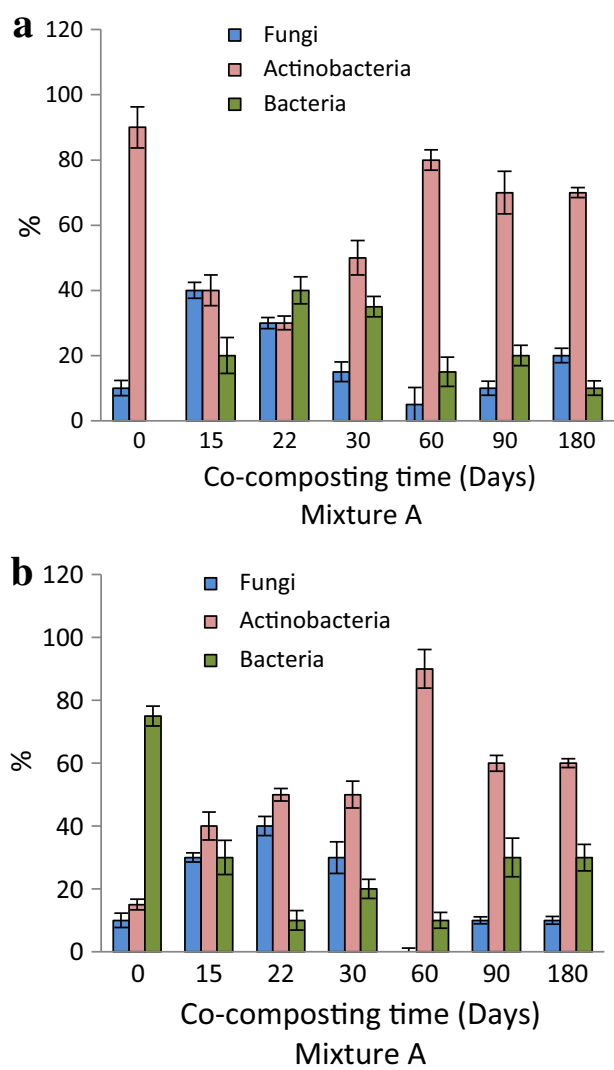
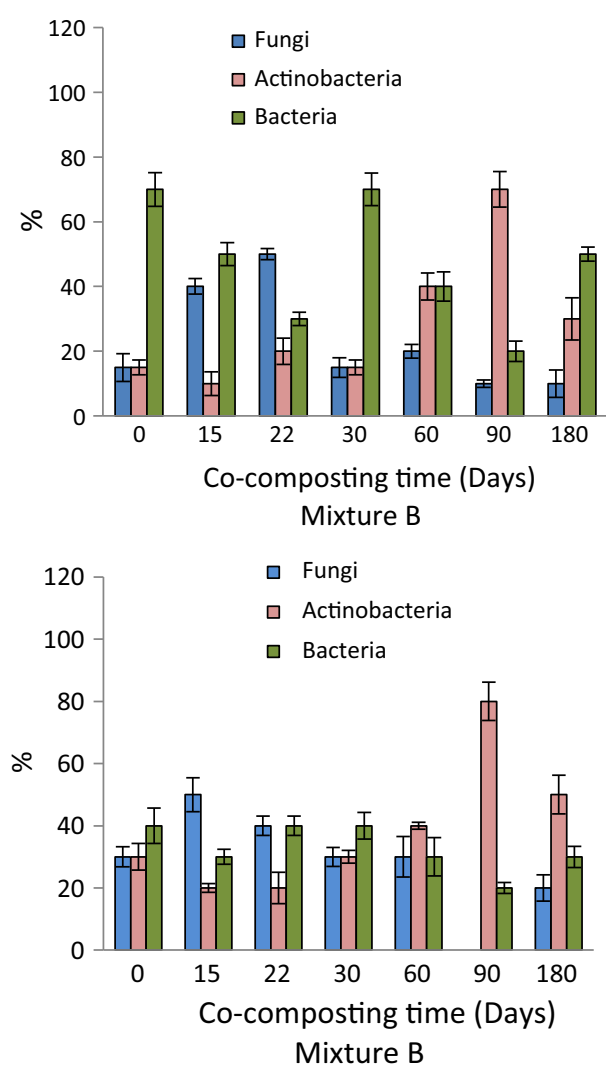


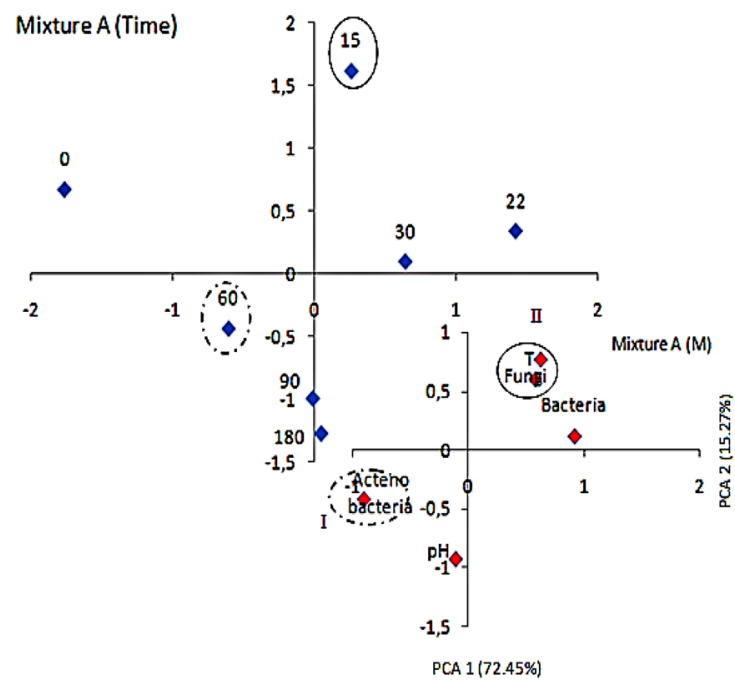

b

Mixture A (Time)

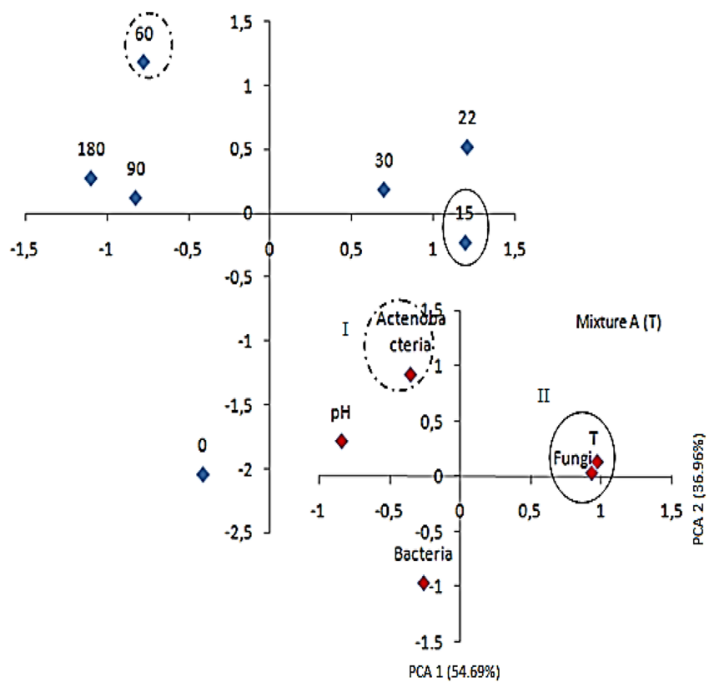

Fig. 4 a Principal components analysis (PCA) between mesophilic microflora evolution and physico-chemical parameters versus time for mixtures A and B. $M$ mesophilic. b Principal components analysis

90 and $80 \%$ for thermophilic microflora, respectively, for mixtures $\mathrm{A}$ and $\mathrm{B}$ during the maturation phase of cocomposting (Fig. 3a, b). Partanen et al. (2010); Kurola et al. (2011) demonstrated that high proportions of actinobacteria indicate good composting conditions.

The results of the (PCA) run between the all identified mesophilic and thermophic microflora profile and physicochemical parameters, during co-composting, show that the actinobacteria (domain I) are inversely correlated with temperature and highly correlated with $\mathrm{pH}$ (case of mixture B) (Fig. 4a, b), which can explain their high evolution, especially during the maturation phase when $\mathrm{pH}$ increases
Mixture B (Time)
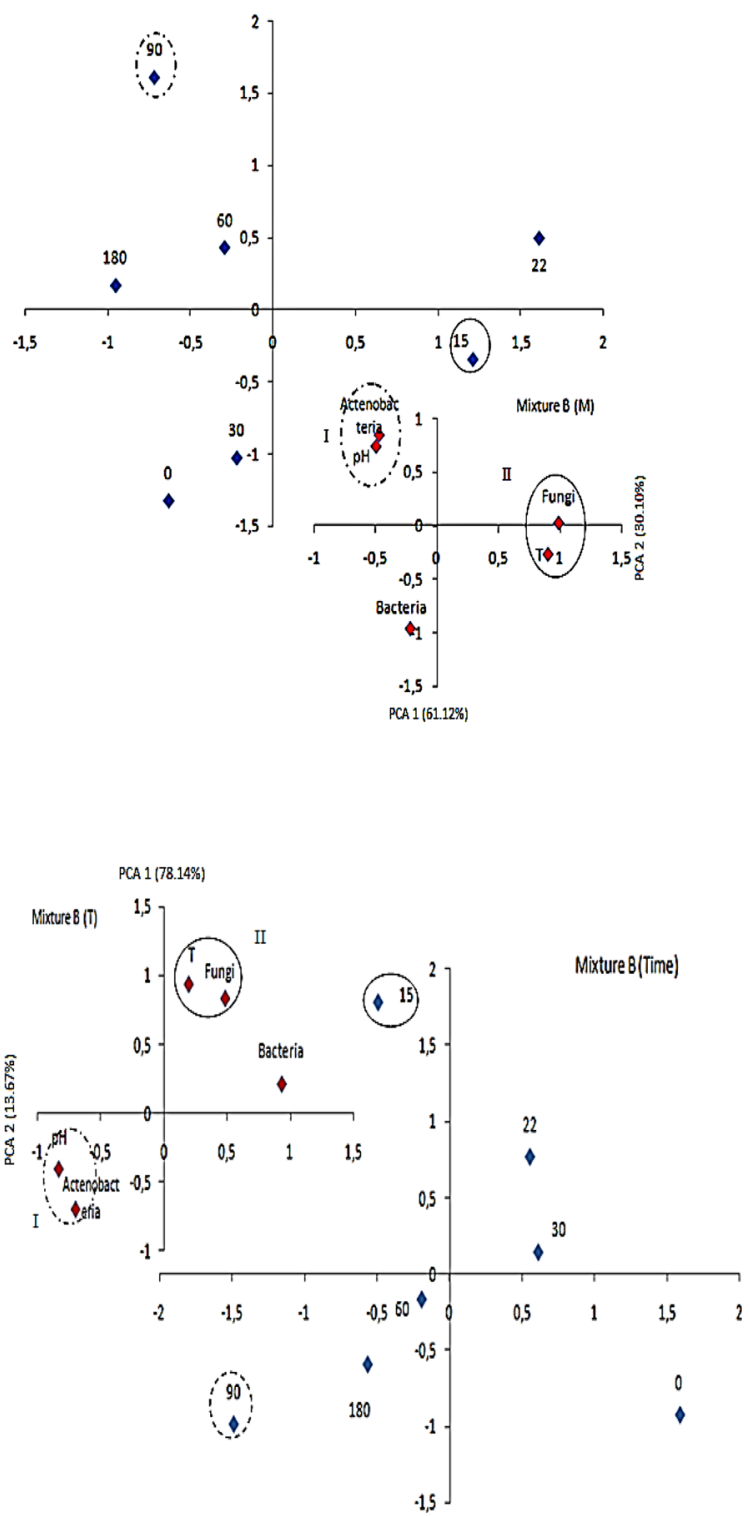

(PCA) between thermophilic microflora and physicochemical parameters versus time for mixtures A and B. $T$ thermophilic

and temperature decreases significantly. However, some actinobacteria isolates in this study were thermotolerant (results not shown). Partanen et al. (2010) and Sundberg et al. (2011) showed a correlation between a rising $\mathrm{pH}$ with an increase in actinobacteria. However, Goodfellow and Williams (1983) reported that various actinobacteria are involved in all compost stages which demonstrates a wide temperature range for their growth, often with an optimum between 25 and $30{ }^{\circ} \mathrm{C}$ for mesophiles and $45-55^{\circ} \mathrm{C}$ for thermophiles.

As reported by Tuomela et al. (2000), the enzymatic capacity of actinobacteria to attack recalcitrant molecules 
explains their activity and their proliferation during the maturation stage. This could explain the increase of actinobacteria groups during the co-composting of lignocellulose-based waste (Fig. 3a, b). However, towards the end of the process the actinobacteria group shows a drop in mixture B and slightly decreases in mixture A. This could be related to the richness of lignocellulose substrate in mixture A. Pérez et al. (2002) and Nakasaki et al. (2009) showed that actinobacteria produce an active enzyme to degrade lignocellulotic compounds. Tuomela et al. (2000); Steger et al. (2007) and Xiao et al. (2011) have shown that actinomycetes are activated later and contribute to the degradation of recalcitrant compounds and the formation of the stable compounds of "humic substance".

The fungal microflora increases during the thermophilic stage of co-composting. They reached 40 and $50 \%$ for the mesophilic and thermophilic microflora of mixtures A and B, respectively (Fig. 3a, b). The PCA shows that fungi, temperature and day 15 (when temperature is around $65{ }^{\circ} \mathrm{C}$ ) (Fig. 4a, b) are highly correlated for both mesophilic and thermophilic microflora. This can explain that the fungal microflora of co-composted substrates is especially the thermotolerant type.

During the intermediate stage the fungal microflora decreased, and this is due to the decrease of temperature. Nevertheless, toward the end a reinstatement of fungal microflora was noted. Chroni et al. (2009) explained that the thermophilic fungi exhibited a small increase as temperature rose in the first month of composting, stabilizing thereafter. Steger et al. (2007), showed that fungi and actinobacteria commonly proliferate during periods with comparatively low temperatures $\left(<45^{\circ} \mathrm{C}\right)$. Several authors show that the final phase, which includes both coolingdown and maturation stages, is characterised by the development of a new mesophilic fungal community (Finstein and Morris 1975; Ishii et al. 2000). Ait Baddi et al. (2004) reported that during the maturation phase, the biodegradation is limited to complex compounds such as high-molecular-weight lignocelluloses. Mouchacca (1997), identified a fungus which has been studied in detail owing to its capacity to produce cellulase and the enzyme able to degrade the lignin in the range of $36-40{ }^{\circ} \mathrm{C}$ with a maximum for $40-46{ }^{\circ} \mathrm{C}$. The fungi with their lignolytic enzymatic capacity can release small aromatic subunits by depolymerization as shown by Kirk and Farrell (1987), which can explain their development on lignocellulosic substrates at the end of co-composting and their contribution to degradation of substance and stabilization of the end products.

The change in the mesophilic microbial population of co-composting, generally, bacteria and yeasts, showed a rise-fall-rise trend; this pattern is due to the nature and life styles of these microorganisms determined by physicochemical conditions. Tuomela et al. (2000) showed that during the co-composting process, the microbial community must adapt to gradually reduced nutrients, oxygen and water with compost maturity. Principal components analysis (PCA) shows that bacteria were never correlated with temperature (Fig. 4a, b).

Bhatia et al. (2013) demonstrated that mesophilic microflora are critical for the degradation of organic substrates which in turn leads to a rapid increase in temperature. The easily metabolisable substrate exhaustion and impoverishment lead to cooling of the windrow; this new condition encourages the installation of the second cocomposting mesophilic microflora (bacteria-yeast; fungus; and actinomycetes) (Fig. 3a). Chroni et al. (2009) show that high numbers of proteolytic bacteria can be expected to appear after the end of the thermophilic stage, as a result of a large amount of proteins that are released when microorganisms die.

The various indigenous microflora such as bacteria, actinobacteria and fungi in composted sewage sludge and date palm waste have the ability to breakdown organic matter. On the other hand, the decrease of temperature and nutrient limitation with compost maturity causes a significant change in the indigenous microflora. Furthermore the temperature is one of the key indicators of co-composting and determines the rate at which many of the biological processes take place and plays a selective role on the succession of the microbiological communities.

\section{Conclusion}

After 6 months of co-composting, the results concluded as to the growth of significant functional microbial communities, by using the CTEA medium adjusted to composting time and recorded $\mathrm{pH}$. Three cultivable and functional indigenous groups were enumerated: actinobacteria, bacteria and fungi. The functional actinobacteria group presented a peak during the maturation stage, especially for mixture A. The bacterial diversity revealed in the co-composting process underwent the changes linked to variations in temperature and availability of new metabolic substrates. In addition, the co-composted substrates are characterised by the abundance of thermotolerant fungi.

Enterococci and the thermotolerant coliforms decreased significantly during the co-composting process which indicates the safety and sanitization of the end product.

The results presented in this study give new information on how the development of the compost microbial community structure is linked to the co-composting time. 
Open Access This article is distributed under the terms of the Creative Commons Attribution License which permits any use, distribution, and reproduction in any medium, provided the original author(s) and the source are credited.

\section{References}

Adani F, Lozzi P, Genevini P (2001) Determination of biological stability by oxygen uptake on municipal solid waste and derived products. Compost Sci Util 9:163-178

Ait Baddi G, Alburquerque JA, Gonzálvez J, Cegarra J, Hafidi M (2004) Chemical and spectroscopic analyses of organic matter transformations during composting of olive mill wastes. Int Biodeterior Biodegrad 54:39-44

Amir S, Hafidi M, Merlina G, Hamdi H, Jouraiphy A, El Gharous M, Revel JC (2005) Fate of polycyclic aromatic hydrocarbons during composting of lagooning sewage sludges. Chemosphere 58:449-458

Barakate M, Ouhdouch Y, Oufdou K, Beaulieu C (2002) Characterization of rhizospheric soil streptomycetes from Moroccan habitats and their antimicrobial activities. World $\mathrm{J}$ of Microbiol Biotechnol 18:49-54

Barje F, El Fels L, El Hajjouji H, Amir S, Winterton P, Hafidi M (2012) Molecular behaviour of humic acid-like substances during co-composting of olive mill waste and the organic part of municipal solid waste. Int Biodeterior Biodegrad 74:17-23

Bhatia A, Madan S, Sahoo J, Ali M, Pathania R, Kazmi AA (2013) Diversity of bacterial isolates during full scale rotary drum composting. Waste Manag 33:1595-1601

Bulina TI, Alferova IV, Terekhova LP (1997) A novel approach to isolation of actinomycetes involving irradiation of soil samples with microwaves. Microbiology 66:231-234

Chroni C, Kyriacou A, Georgaki I, Manios T, Kotsou M, Lasaridi K (2009) Microbial characterization during composting of biowaste. Waste Manag 29:1520-1525

Cofie OO, Agbottah S, Strauss M, Esseku H, Montangero A, Awuah E, Kone D (2006) Solid-liquid separation of faecal sludge using drying beds in Ghana: implications for nutrient recycling in urban agriculture. Water Res 40:75-82

De Bertoldi M, Vallini G, Pera A (1983) The biology of composting: a review. Waste Manag Res 1:167-175

El Fels L, El Ouaqoudi F-Z, Barje F, Hafidi M, Ouhdouch Y (2014a) Two culture approaches used to determine the co-composting stages by assess of the total microflora changes during sewage sludge and date palm waste co-composting. J Environ Health Sci Eng 12:132

El Fels L, Zamama M, El Asli A, Hafidi M (2014b) Assessment of biotransformation of organic matter during co-composting of sewage sludge-lignocelullosic waste by chemical FTIR analyses and phytotoxicity tests. Int Biodeterior Biodegrad 87:128-137

Epstein E (1997) The science of composting Lancaster. Technomic Publishing Company, Lancaster

Filippi C, Bedini S, Levi-Minzi R, Cardelli R, Saviozzi A (2002) Cocomposting of olive oil mill by-products: chemical and microbiological evaluations. Compos Sci Util 10(1):63-71

Finstein MS, Morris ML (1975) Microbiology of municipal solid waste composting. Adv Appl Microbiol 19:113-151

Gaspard PG, Schwartzbrod J (2003) Parasite contamination (helminth eggs) in sludge treatment plants: definition of a sampling strategy. Int J Hygiene Environ Health 206:117-122

Goodfellow M, Williams ST (1983) Ecology of actinomycetes. Annu Rev Microbiol 37:189-216

Hassen A, Belguith K, Jedidi N, Cherif A, Cherif M, Boudabous A (2001) Microbial characterization during composting of municipal solid waste. Bioresour Technol 80:217-225
Herrmann RF, Shann JF (1997) Microbial community changes duringthe composting of municipal solid waste. Microb Ecol 33:78-85

Ishii K, Fukui M, Takii S (2000) Microbial succession during a composting process as evaluated by denaturing gradient gel electrophoresis analysis. J Appl Microbiol 89:768-777

Jakobsen ST (1995) Aerobic decomposition of organic wastes 2. Value of compost as fertilizer. Resour Conserv Recycl 13:57-71

Kirk TK, Farrell RL (1987) Enzymatic "combustion": the microbial degradation of lignin. Annu Rev Microbiol 41:465-505

Klammer M, Baath E (1998) Microbial community dynamics during composting of straw material studied using phospholipid fatty acid analysis. FEMS Microbiol Ecol 27:9-20

Koné D, Cofie O, Zurbrugg C, Gallizzi K, Moser D, Drescher S, Strauss M (2007) Helminth eggs inactivation efficiency by faecal sludge dewatering and co-composting in tropical climates. Water Res 41:4397-4402

Kurola JM, Arnold M, Kontro MH, Talves M, Romantschuk M (2011) Wood ash for application in municipal biowaste composting. Bioresour Technol 102:5214-5220

Lung AJ, Lim CM, Kim JM, Marshall MR, Nordstedt R, Thompson NP, Wei CI (2001) Destruction of Escherichia coli O157:h7 and Salmonella enteritidis in cow manure composting. J Food Prot 64:1309-1314

Marshall MN, Reddy AP, Vander Gheynst JS (2004) Microbial ecology of compost. In: Lens P, Hamelers B, Hoitink H, Bidlingmaier W (eds), Resource Recovery and Reuse in Organic Solid Waste Management. IWA Publishing, London, pp 193-224

Mouchacca J (1997) Thermophilic fungi: biodiversity and taxonomic status. Cryptogamie Mycol 18:19-69

Nakasaki K, Tran LTH, Idemoto Y, Abe M, Rollon AP (2009) Comparison of organic matter degradation and microbial community during thermophilic composting of two different types of anaerobic sludge. Bioresour Technol 100:676-682

Olson EH (1968) Actinomycetes isolation agar. In: Difco: supplementary literature. Difco Lab Detroit, Michigan

Ouhdouch Y, Barakate M, Finance C (2001) Actinomycetes from Maroccan habitats: screening for antifungal activities. Eur J Soil Biol 37:1-6

Palmisano AC, Barlaz MA (1996) Microbiology of solid waste. CRC Press, Boca Raton

Paniel N, Rousseaux S, Gourland P, Poitrenaud M, Guzzo J (2010) Assessment of survival of Listeria monocytogenes, Salmonella infantis and Enterococcus faecalis artificially inoculated into experimental waste or compost. J Appl Microbiol 108:1797-1809

Partanen P, Hultman J, Paulin L, Auvinen P, Romantschuk M (2010) Bacterial diversity at different stages of the composting process. BMC Microbiol 10:94

Paul EA, Clark FE (1996) In: 2nd edn. Soil microbiology and biochemistry. Academic Press, San Diego

Pietronave S, Fracchia L, Rinaldi M, Martinotti MG (2004) Influence of biotic and abiotic factors on human pathogens in a finished compost. Water Res 38:1963-1970

Pérez J, Munoz-Dorado J, de la Rubia TDLR, Martinez J (2002) Biodegradation and biological treatments of cellulose, hemicellulose and lignin: an overview. Int Microbiol 5(2):53-63

Redlinger T, Graham J, Corella-Barud V, Avitia R (2001) Survival of faecal coliforms in dry-composting toilets. Appl Environ Microbiol 67:4036-4040

Riddech N, Klammer S, Insam H (2002) Characterisation of microbial communities during composting of organic wastes. Springer, Berlin, Heidelberg, pp 43-51

Ryckeboer J, Mergaert J, Coosemans J, Deprins K, Swings J (2003) Microbial aspects of biowaste during composting in monitored compost bin. J Appl Microbiol 94:127-137 
Shirling EB, Gottlieb D (1966) Methods for characterization of Streptomyces species. Int J Syst Bacteriol 16:313-340

Sidhu J, Gibbs RA, Ho GE, Unkovich I (2000) The role of indigenous microorganisms in suppression of Salmonellare-growth in composted biosolids. Water Res 35:913-920

Sneath PHA, (1986) Endospore-forming gram-positive rods and cocci. In: Bergey's Manual of Determinative Bacteriology, vol 2. William \& Wilkins, USA, pp 1104-1207

Steger K, Sjogren AM, Jarvis A, Jansson JK, Sundh I (2007) Development of compost maturity and Actinobacteria populations during full-scale composting of organic household waste. J Appl Microbiol 103:487-498

Sundberg C, Franke-Whittle I, Kauppi S, Yu D, Romantschuk M, Insam H, Jönsson H (2011) Characterisation of source-sorted household waste intended for composting. Bioresour Technol 102:2859-2867

Tønner-Klank L, Møller J, Forslund A, Dalsgaard A (2007) Microbiological assessments of compost toilets: in situ measurements and laboratory studies on the survival of faecal microbial indicators using sentinel chambers. Waste Manag 27:1144-1154

Tuomela M, Vikman M, Hatakka A, Itavaara M (2000) Biodegradation of lignin in a compost environment: a review. Bioresour Technol 72:169-183

Vuorinen AH, Saharinen MH (1997) Evolution of microbiological and chemical parameters during manure and straw co-composting in a drum composting system. J Agric Ecosyst Environ 66:19-29

Wei Z, Xi B, Zhao Y, Wang S, Liu H, Jiang Y (2007) Effect of inoculating microbes in municipal solid waste composting on characteristics of humic acid. Chemosphere 68:368-374

Xiao Y, Zeng GM, Yang ZH, Ma YH, Huang C, Xu ZY, Huang J, Fan CZ (2011) Change in actinomycetal communities during continuous thermophilic composting as revealed by denaturing gradient gel electrophoresis. Bioresour Technol 102:1383-1388 